\title{
UNDERSTANDING ATTITUDE TOWARDS INDIAN ADVERTISING AMONG THE YOUNG CONSUMERS
}

\author{
DR. GURCHARAN SINGH ${ }^{1}$, DR. JASKIRAT SINGH RAI ${ }^{2}$, DR. GURPREET SINGH SIDHU ${ }^{3} \&$ \\ KANWARVIR SINGH KHAIRA ${ }^{4}$ \\ School of Management Studies, Punjabi University, Patiala, Punjab, India \\ Chandigarh Group of Colleges, Landran, Punjab, India
}

Chandigarh Business School of Administration, Punjab State Aeronautical Engineering College, Patiala, Punjab, India

Department of Management, School of Management Studies, Punjabi University, Patiala, Punjab, India

\begin{abstract}
While basics of any culture are carried on by discarnate and exemplary possibility accomplished from the gathering place and finally the media which establish prevailing of limited culture far and wide to overall population. Fringe to any nation, it is the social aspects that sway the advertising dread in substance to the winnowing of the media, advertising extraction and in particular the illustrative grasp. The current researchis avowed to secure the Indian advertising on regular ground. Taking into account Marketing Mix, determinants involving the advertising prospect are transcendently brought about by dissimilarity of culture and change of lifestyle as well as attitude among young consumer. The Study is expanded for entire of the host country, targets of the five zones, which included of the equivalent number of respondents from each zone-North, South, East, West and Center. Stratified Random Sampling was emphasized as a result of its high accuracy and allocates discrete estimate for each sub-gathering. According to the need of the study, the sample size taken is 600 as accord to the sample populace.On one hand, it is erroneous to decide advertising either in an excessively homogeneous or either heterogeneous countries, yet on other hand, it is the essentialto get on the consumer needs, scrutinize crucial markings and perceiving of conduct toward efficacious advertising. Standardization of advertising perhaps suitable to little degree, where the conscienceis either reaching out along with culture of the nation.
\end{abstract}

KEYWORDS: Advertising, Young Consumer, Factor Analysis, India

Received: Jun 08, 2020; Accepted: Jun 28, 2020; Published: Aug 31, 2020; Paper Id.: IJMPERDJUN2020983

\section{INTRODUCTION}

To gratify the unexpected drive for western anticipate, Asian nations likewise spread out interestedness in comparative style of living and exigency [1]. Considering to the local context, Asian individuals is destined to local slang and bond with native indication [2]. Account of Asian scenario, it is perceived of social peculiarity and from this time forward essential to spotlight on culturally diverse investigation. While basics of any culture are carried on by values as well as lifestyles and finally the media [3] which prevails of sub-culture far and wide to overall population. Also, in light of the global organizations who wish to extend in Asian system shall have accepted reflection of the demand and further locating of definite culture before setting out upon the target of advertising [4]. Across intricate culture, unfamiliar advertisements strove for because of social push that outlines the exact features and spontaneous to come up with [5]. Fringe to any nation, it is the social aspect that implies control on the advertising in substance to winnowing of the media, advertising subject extraction and above all the 
illustrative grasp. In light of a legitimate concern for up surging benchmark of living in Asian sketch which is prompted to some extent with global advertising technique, demonstrating contrast not either for the fulfilmentof articulation or attaining to rationality [6].

As the entire world is speculate under one, the individuals yet have excitement for the foreignproducts and conspicuous way of life [7]. Same taking into consideration of global brands, albeit little influence towards the purchasing of such brands [8]. Notwithstanding to convince the buyer, the advertising presentation was brought into application, where the advertisements overflow to geological quirk, coordinate style of living and observingeconomic conditions [9]. All things considered, advertising concede the expansion of society, it is impulse for to imagine of the culture and their values[10], and besides crusades in thinking ahead of host individuals in portrayal of the population [11]. Considering to the advertising validation, the meddling to clarify the social objectivity in describe to global advertising is a significant issue in extent of uphold [12]. The two components are articulated as of advertising: (1) What thought should be channelized, containing of the compelling picture, and (2) conferral will be with the end goal that it involves both recognizable and selective communicated matter directed toward core of the advertising message, the social obligation is pointed[13]. The current research was pointed to contemplate Indian advertising on customary ground. Development of all-encompassing interests in Indian markets and though getting immense costs progressed towards number boosting up for the advertising in India [14]. Significant predecessors drawing nearer to extension of advertising are: fast development of a country, good access for the global organizations, growing of media and amplification of consumer mindfulness [15]. Advertisements which enhances the culture thus exhibit their demand and moreover convey of emblematic implications. However, there is a negligible requirement for advertiser to support relevance immensity of the culture and their conscience, on the grounds that culture is structured of principles among individuals. Subsequently, advertisers permit themselves to come up with unique characteristics in advertisements which can be both effective and productiveas set out toward the social acquaintance.

On one hand, it is precarious to decide advertising either in an excessively homogeneous or either heterogeneous countries, yet on other handit is the essential to get on the buyer needs, discuss priorities and the perceiving of conduct toward generous advertising [16]. [17] On and the off chance that entire of the Indian population could be activated to the screening of a similar exhibit towards the recovering of huge sum related with it. However, this is IMPOSSIBLE! Standardization of advertising could be fitting to little degree, where the characteristics are either stretching out along and presence of especially indistinguishable culture. Considering of Marketing Mix, determinants including the advertising prospect are prevalently brought about by disparity in culture and understanding of the attitude and behaviour [18]. With everything taken into account the advertising confabulates of culture and predicate set of order toexhibition [19]. Reckoning to current study, Pollay scale is featured to scrutinize attitude apropos advertising.

\section{METHODOLOGY}

The Study is broadened of the host nation, from where the researcher can undoubtedly reach to and gathered the appropriate information. Examining of the research depends on the five zones, which included of the equivalent number of respondents from each zone North, South, East, West and Center. The Youth of the nation was chosen as the respondent for the investigation of the fact that - (i) they contribute generally appertaining to Indian public, (ii) it is the youth which is getting more materialistic, grasping to new innovation, changing their way of life, and moving towards the westernized aspect. Information was gathered using questionnaire from the colleges which are giving degree towards the accomplishment in Master of Business Administration. Stratified Random Sampling was emphasized as a result of its high 
accuracy and too allocates discrete speculation for each sub-gathering [20]. According to need of the research, the determined sample size is 600 as seeking to the sample outlook. The central focus of current researchrevolved around the questionnaire, which was both validity and reliability checked before the assortment of information. Meeting to the requisite of data and satisfying the presumption, Factor Analysis was brought into applicability.

Table 1: Reliability Statistics

\begin{tabular}{|c|l|c|}
\hline Scale & Cronbach's Alpha & N of Items \\
\hline Pollay Attitude to Advertising & .701 & 29 \\
\hline
\end{tabular}

The Cronbach's alpha scores has achieved the limit estimation of 0.7 and was ascertained which came out 0.701 after computation through SPSS Reliability Analysis test, proposing the inside consistency.Pollay scale demonstrated adequately dependable in Indian angle. WithFactor Analysis, it is conceivable to put substantively important imperatives on the factor show, setting the impact of one inactive variable to rise to zero on a subset of the watched factors.A build is "approved" by sensible contention and experimental techniques, more often than not a legitimacy coefficient or potentially factor examination.

Table 2: Determine the Model Fit

\begin{tabular}{|c|c|c|c|}
\hline Scale & KMO > 0.7 & Cumulative Variance Explained > 60\% & N of Items \\
\hline Pollay Attitude to Advertising & .708 & 61.008 & 29 \\
\hline
\end{tabular}

\section{DATA ANALYSIS \& RESULTS}

For current study, Exploratory Factor Analysis was analyzed because it is the first time the similar standardised scale is applied in Indian scenario, as most of work related to it is done in American or European context. As value of KMO exceedsmore than 0.7, it reflects as data is suitable to conduct the factor analysis. Moreover, Chi-Square under Bartlett's Test of Sphericity is also significant which indicates to the identity matrix which is non-zero. Cumulative Variance Explained is more than $60 \%$, it means construct is explaining sum total of 60 percent of variance, which too proves the construct validity. Adopted Scale of Pollay \& Mittal was considered for the present study which includes of the 29 statements, from which the 10 statements were discarded as considering to the Communalities extraction table where the numerical extraction was less than.5 for all the 10 statements. Rest remaining statements are computed as following with the numerical extraction value.

Table 3: Communalities

\begin{tabular}{|l|c|c|}
\hline & Initial & Extraction \\
\hline Quite often advertising is amusing and entertaining & 1.000 & .694 \\
\hline Advertising persuades people to buy things they should not buy & 1.000 & .548 \\
\hline Advertising helps raise our standard of living & 1.000 & .534 \\
\hline Advertising results in better products for the public & 1.000 & .650 \\
\hline $\begin{array}{l}\text { Advertising is making us a materialistic society, overly interested in buying and } \\
\text { owning things }\end{array}$ & 1.000 & .576 \\
\hline Advertising tells me which brands have the features I am looking for & 1.000 & .661 \\
\hline Advertising makes people buy unaffordable products just to show off & 1.000 & .534 \\
\hline In general, advertising results in lower prices & 1.000 & .618 \\
\hline $\begin{array}{l}\text { Advertising helps me keep up to date about products/services available in the } \\
\text { marketplace }\end{array}$ & 1.000 & .662 \\
\hline Overall, I consider advertising a good thing & 1.000 & .665 \\
\hline Advertising makes people live in a world of fantasy & 1.000 & .539 \\
\hline There is too much sex content in advertising today & 1.000 & .641 \\
\hline Some products/services promoted in advertising are bad for our society & 1.000 & .611 \\
\hline \multicolumn{1}{|c|}{ Extraction Method: Principal Component Analysis. } \\
\hline
\end{tabular}


Eigen Value emphasizing was applied over number of factors defined method with sum iterations of 50, followed by the Principal Component Analysis rotated in varimax. Those factors were considered which has the eigen value more than 1. Furthermore, one statement was removed as due to the negative factor loading in the Rotated Component Matrix table plus five statements did not have any numerical value or factor loadings as tabulated in Rotated Component Matrix table, where defined as sorted by size plus suppressed small coefficients absolute value below.5. As remaining statements has the communality extraction significant, hence five factors sum up explaining variance more than 60 percent for each eigen value is more than one.Paramount and substantial monetary essence of advertising are scrutinized under good for economy factor. Materialism, Value Corruption and Consumer Manipulation factors allow understanding to the initiation of advertising notion and added concealment of cunning mark based on advertising. Falsity factor is made emphatic to extend the deception, erroneousness and fraudulence in dominion of advertising.

Table 4: Rotated Component Matrix

\begin{tabular}{|c|c|c|c|c|c|}
\hline & \multicolumn{5}{|c|}{ Component } \\
\hline & 1 & 2 & 3 & 4 & 5 \\
\hline $\begin{array}{l}\text { Advertising helps me keep up to date about } \\
\text { products/services available in the marketplace }\end{array}$ & .802 & & & & \\
\hline Overall, I consider advertising a good thing & .785 & & & & \\
\hline $\begin{array}{l}\text { Advertising tells me which brands have the features I am } \\
\text { looking for }\end{array}$ & .746 & & & & \\
\hline $\begin{array}{l}\text { Advertising persuades people to buy things they should } \\
\text { not buy }\end{array}$ & & .726 & & & \\
\hline $\begin{array}{l}\text { Advertising is making us a materialistic society, overly } \\
\text { interested in buying and owning things }\end{array}$ & & .694 & & & \\
\hline $\begin{array}{l}\text { Advertising makes people buy unaffordable products just } \\
\text { to show off }\end{array}$ & & .639 & & & \\
\hline Advertising results in better products for the public & & & .756 & & \\
\hline Advertising helps raise our standard of living & & & .671 & & \\
\hline Advertising makes people live in a world of fantasy & & & .560 & & \\
\hline There is too much sex content in advertising today & & & & .782 & \\
\hline $\begin{array}{l}\text { Some products/services promoted in advertising are bad } \\
\text { for our society }\end{array}$ & & & & .739 & \\
\hline Quite often advertising is amusing and entertaining & & & & & .765 \\
\hline In general, advertising results in lower prices & & & & & .623 \\
\hline $\begin{array}{l}\text { Extraction Method: Principal Component Analysis. } \\
\text { Rotation Method: Varimax with Kaiser Normalization. }\end{array}$ & & & & & \\
\hline
\end{tabular}

Considering to the Study, following set of statements, where advertising is marked a good thing plus keeps one updated on new services provided and availability of products present in the market, and last whether the particular brands fulfil the requirement of various features in it are all determined under the first factor. Following statements such as, where the advertising in the present scenario forces one to show off from their side by purchasing on the unnecessary items, which may be expensive leading towards materialistic society as well as interests individuals towards the buying of things, which either has no use or bought under the influence of impulse buying, which fall under the second factor. In context of third factor which comprises of as better and much needed products are advertised in context to the public nowadays which too allows raising the local standards among individuals plus better their living aspect, though also sometimes puts one in a situation where the individuals see them in virtual world instead of facing the reality. Last two factors, which in each has the two statements beneath them where first included of as today the sexuality content take into account is highly present in the advertisements plus some products provided or services offered have not good impact as relate to the society, well 
publicized in any form of advertising. Furthest, the last two statements which contribute are, as advertising results to usually lowering down the prices together with as often times treated both amusing plus entertaining.

\section{CONCLUSIONS}

To current times, the advertisers are conscientious to young people who doesn't show or show very less interest towards Indian items. Young generation shows interest towards global brands that unavoidably permits to changing tastes and attitude consideringbuying behaviour. It is the young age number in India who are responsive to global advertisements in comparison to elder group. The appeal 'sex' isn't observed as susceptible in the Indian advertisements. India as a nation comprising one culture amount to individuals, family, society, religion and sub-culture doesn't affirm of closeness between other gender in the Indian advertisements. However international marketer can't underwrite for the unitary standardization approach in Indian conditions or oppositely whole adaptation approach be going to make insistent.On opposed to the Asian countries, some portion of standardization[21] may be acquired to use seeing of appropriate diversity in culture. The standardanticipation for the marketer is to perceive the local covet [22] whichever be capable to 'universal appeals', and that opportunity let on to prosperbefore standardization. The intervention of standardization implies to arrange for future urgingproductive for hypothetical plot as outcome associated withsystematicdepiction of the proceeding.

\section{REFERENCES}

1. Sinha. (1988). Basic Indian values and behaviour dispositions in the context of national development: An appraisal. In D. Sinha, \& H. Kao, Social values and development: Asian perspectives (pp. 31-55). New Delhi: Sage.

2. Lane, P. (2002). A Beginner's Guide to Crossing Cultures: Making Friends in a Multinational World. Downers Grove, IL: Intervarsity.

3. Schiffman, L. G., \& Kanuk, L. L. (2000). Consumer Behavior. New Jersey: Prentice Hall.

4. Fam, \& Grohs. (2007). Cultural values and effective executional techniques in advertising: A cross-country and product category study of urban young adults in Asia. International Marketing Review, 24 (5), 519-538.

5. Zhang, Y., \& Gelb, B. D. (1996). Matching Advertising Appeals to Culture: The Influence of Product's Use Conditions. Journal of Advertising, 25 (3), 29-46.

6. Tai, S. H. (1997). Advertising in Asia: localize or regionalize? International Journal of Advertising, 16 (1), $48-61$.

7. Levitt, T. (1983). The globalization of market. Harvard Business Review, 61, 92-102.

8. Mooij, M. D. (1998). Global Marketing and Advertising: Understanding Cultural Paradox. Thousand Oaks, CA: Sage.

9. Bell, A. (2001). "Bugger!": Media language, identity and post modernity in Aotearoa/New Zealand. New Zealand Sociology, $16(1), 128-150$.

10. Harris, G. (1984). The Globalization of Advertising. International Journal of Advertising, 3 (3), 223-234.

11. Srikandath, S. (1991). Cultural Values depicted in Indian Television Advertising. Gazette, 48, 165-176.

12. Zou, S. (2005). Contribution to international advertising research. Journal of Advertising, 34 (1), 99-110.

13. Albers-Miller, N. D., \& Gelb, D. D. (1996). Business advertising appeals as mirror of cultural dimension. Journal of Advertising, 25 (4), 57-70.

14. Kemp, G. (1995, May 12). "India". The Campaign Report, p. 13. 
15. Patel. (2010). Indian Advertising Industry. Retrieved May 5, 2018, from http://www.scribd.com/doc/28302409/IndianAdvertising-Industry.

16. Belk, R. W., \& Pollay, R. W. (1985). Materialism and Status Appeals in Japanese and U.S. Print Advertising: A Historical and Cross-Cultural Content Analysis. International Marketing Review, 2 (12), 38-47.

17. Dahl, S. (2005). Cross cultural advertising research what do we know about influence of culture on advertising. (L. Middlesex University, Ed.) Retrieved May 5, 2018, from http://ssrn.com/abstract658221.

18. Cateora, P. R., \& Graham, J. L. (2002). International Marketing. McGraw Hill.

19. An, D. (2006). A content analysis of multinational advertisers' localization strategy in web advertising. International Journal of Internet Marketing and Advertising, 3 (2), 120-141.

20. Rai, J.S., and Singh, A. (2019), “The Impact of Team Association on Fans' Product Knowledge and Purchase Intentions: A Case of Indian Premier League”, IIM Kozhikode Society \& Management Review, Vol. 1 No. 11, Doi: 10.1177/2277975219871341.

21. James, W. L., \& Hill, J. S. (1991). International advertising messages: to adapt or not to adapt. Journal of Advertising Research, 31 (3), 65-70.

22. Appadurai, A. (1990). Disjuncture and difference in the global cultural economy. Public Culture, 2, 1-24. 